\title{
The Use of the Bits and Pieces Game on Students' Achievement on Writing Report Text
}

\author{
Ramanda Rizky ${ }^{1}$, Yetty Zainil 2
}

DOI: 10.35445/alishlah.v13i1.463

\begin{abstract}
Article Info
Abstract

Keywords:

The Bits and pieces

game

Writing skills

Report text

Language learning

This experimental research intended to examine the effects of the Bits and Pieces game on students' achievement in the writing report text. Sixty-eight students in the tenth grade participated in an experimental class taught through the Bits and pieces game. The participants in the control class taught through the Conventional teaching method. After the treatment was done, the students in both grades were tested. As the results, the mean average showed that there was an increase in writing scores. Additionally, the score in the experimental class showed that the Bits and Pieces game was adequate to be taught. Nevertheless, the score in the control class showed that the Conventional teaching method was not effective to be taught because there was no significant difference between the score in the pre-test and post-test. Furthermore, learning through the Bits and Pieces game encourages students' broader skills of cooperation and negotiation.
\end{abstract}

Kata kunci:

The Bits and pieces game

Kemampuan menulis

Teks report

Pembelajaran bahasa

\begin{abstract}
Abstrak
Penelitian eksperimental ini bertujuan untuk menguji pengaruh the Bits and Pieces terhadap prestasi belajar siswa dalam menulis teks report. Sebanyak 68 siswa kelas X yang mengikuti kelas eksperimen diajar melalui the Bits and pieces, dan peserta kelas kontrol diajar dengan the Conventional teaching method. Setelah dilakukan treatment, siswa di kedua kelas tersebut di tes. Hasilnya, rata-rata rata-rata menunjukkan adanya peningkatan nilai menulis. Selain itu, skor di kelas eksperimen menunjukkan bahwa the Bits and pieces game efektif untuk diajarkan. Namun demikian, skor pada kelas kontrol menunjukkan bahwa the Conventional teaching method tidak efektif untuk diajarkan karena tidak terdapat perbedaan yang signifikan antara skor pretes dan postes. Selain itu, belajar melalui the Bits and Pieces mendorong keterampilan kerja sama dan negosiasi siswa yang lebih luas.
\end{abstract}

\section{INTRODUCTION}

Writing requires one's ability to express ideas, opinions, thoughts, and feeling to be good at writing to understand the written topic. This skill is also notoriously one of the most challenging skills for EFL students to master (Rizky, 2020). Jimmi (2017) added that writing skills are of course, very important in the process of learning English because writing is one of the skills besides reading,

\footnotetext{
${ }^{1}$ Faculty of Languages and Arts, Universitas Negeri Padang, Padang, Indonesia e-mail: ramandarizkyo@gmail.com

${ }^{2}$ Faculty of Languages and Arts, Universitas Negeri Padang, Padang, Indonesia e-mail:yz2009@ymail.com
} 
speaking, and listening. Besides, as a standard of the education system, in English Curriculum 2013 students learn writing in terms of text types like descriptive, narrative, recount, report and procedure.

One of the texts that the students should be acquired is the report text. Report text is a kind of text written by someone or a group of people to report the results of analysis or to the appropriate authorities. Unfortunately, based on observation, the students faced some problem: the students are often difficult to distinguish between the report text and the descriptive text. Furthermore, both of them provide detailed explanations of something. Report text defines something as a whole, not an exact object. For instance, when describing cat animals in general, this is the text of the report.

In addition, the Conventional teaching method is applied in the class. The conventional teaching method is usually oriented to teachers, and students are taught in a way that is conducive to sitting and listening (Tularam \& Machisella, 2018). It means that the teacher always gives activities, oral recitation, lecturing all day, and always give an assignment every day.

This old-fashioned way of teaching was all about recitation. For example, students would sit in silence, while one student after another would take turns to recite the lesson until each one had been called upon. Besides, this situation affected the learning process and ended up with less interaction in the learning process.

Therefore, the researcher attempts to figure out another way to help the students on how to write a report text. Based on the problem above, the researchers chose the Bits and Pieces game to assist students in learning to write a report text. Initially, Andayani (2018) explains that the Bits and Pieces game has a picture-strip to tell. It is also suitable for narrating events and portraying a person, a place or something, particularly in the present tense. Nafsah (2016) said that using Bits and Pieces games in the teaching-learning process can also be used by the teacher to improve students' writing ability. Therefore, the researchers expect the students to be more concerned in writing a report text and writing an appropriate text following the rules of writing a report text.

Furthermore, some studies have been conducted previously related to the use of the Bits and pieces game. A survey conducted by Rojiyah (2017) has revealed that the challenges faced by both teachers and students during teaching and learning practices have arisen. Moreover, the studies by Andayani (2018) and Nurkhayatun (2011) have revealed that the student's response to learning English by using games was very positive, and the Bits and Pieces game was beneficial to increase their writing skills.

Despite some of the research that has figured out the effect of using the Bits and Pieces game in writing, none of these studies focused on figuring out what motivate the students. That is to figure out whether motivation affects students' writing skills in report text or not. The current research aimed at scrutinizing another way for the students to write a report text by using the Bits and Pieces game as the strategy, specifically to answer the question, "Does the use of the Bits and Pieces game have a better effect on students' achievement on writing report text than using the conventional teaching method?” Therefore, as a result, by using the Bits and pieces game as the strategy, the researcher expects that this research would be significant for the students and the teacher to adapt in the writing class.

\section{METHODS}

This research used a quasi-experimental research design (Arikunto, 2013). Therefore, the study employed a pre-test and post-test to extract needed data from one experimental class (EC) and one control class (CC). This research focused on the Bits and Pieces game as an independent variable and Writing a report text as a dependent variable to be influenced by an independent variable. For analyzed the data, the researchers used a T-test. The collected data were analyzed using a T-test.

Moreover, the research participant included 6 classes in the tenth grade of SMAN 1 Tambusai, it is located at Jl. Transmigrasi, No. 58 in the district of Tambusai, and the population in the 6 classes was 148 students. And since random cluster sampling was used to determine the sample, two classes 
were chosen randomly as the sample in the research. Those were X IPA 1 as the experimental class (EC) and X IPA 3 as the control class (CC). Those two classes its included 50 students as participants. They were chosen randomly from the population.

To figure out students' achievement, after implementing the treatment, the researcher gave the writing test to see whether the Bits and Pieces game have a better impact on their achievement or not. The writing test is given to two classes, and it has consisted of two types; those are pre-test and post-test.

The students were given a pre-test to know their achievement by writing the report text. The researchers would provide the students with a pre-test before they got any medication. Moreover, the post-test was conducted after the researcher implemented the treatments (the Bits and Pieces game), and it aimed to measure their achievement in writing report text. Besides, the post-test was conducted in form of a writing test, and the post-test score was taken as the data of the research and then that score was compared to a pre-test.

Also, the treatment lasted 8 meetings for each class of 90 minutes under the guidance of the supervisor for each class. In the last session, both classes took the post-tests of writing. The students' writing skills were assessed using the rubric scoring from Brown (2007), which has consisted of five components: organization, content, grammar, vocabulary, and mechanics. After the treatment period, the researcher measured the effects of the Bits and Pieces game on students' achievement on writing report text.

The researcher used a quantitative data analysis technique, and it was analyzed by statistical method. The collected data through the procedures mentioned earlier were analyzed and interpreted according to the research's objective. Firstly, normality testing will be done to see whether the data collections from both groups are normally distributed. Furthermore, the Lilliefors Test is adapted to analyze the data collected (Sudjana, 2002). Secondly, to examine the data collections, the researchers used a T-test conducted to see the significant effect of the Bits and Pieces game on students' achievement on writing report text.

\section{FINDINGS AND DISCUSSION}

First of all, this research was done in eight meetings in both classes. After the students have carried out the writing exam, the researchers measure the pre-test and post-test score in both classes to test the hypothesis. The researcher calculated both scores using SPSS to identify the effect of the Bits and Pieces game and the Conventional teaching method on students' achievement on writing report text.

The post-test was taken after some treatments given to the students for both experimental and control classes. It was done to know the students' skills in writing report text after the treatment was applied. The scores were classified into six categories; such as excellent, good, fair, less, poor, and very poor. Furthermore, the classification of the score can be seen in the following table:

Table 1. Students' Scores of Post-Writing Test

\begin{tabular}{ccccccccc}
\hline No & Score range & Categories & \multicolumn{2}{c}{ Experimental Class } & \multicolumn{3}{c}{ Control Class } \\
\cline { 5 - 7 } & & & Freq. & F (\%) & Mean & Freq. & F (\%) & Mean \\
\hline 1 & $91-100$ & Excellent & 6 & $24 \%$ & 81.5 & 0 & $0 \%$ & 71.55 \\
\hline 2 & $81-90$ & Very Good & 10 & $40 \%$ & & & 1 & $4 \%$ \\
\hline 3 & $71-80$ & Good & 4 & $16 \%$ & & & 12 & $48 \%$ \\
\hline 4 & $61-70$ & Fair & 5 & $20 \%$ & & & 12 & $48 \%$ \\
\hline 5 & $51-60$ & Poor & 0 & $\%$ & & & 0 & $0 \%$ \\
\hline 6 & $<50$ & Very Poor & 0 & $0 \%$ & & & 0 & $0 \%$ \\
\hline
\end{tabular}


The table above revealed that the students' scores of post-writing test both experimental class and control class. There are six categories to classified the students' score. The table indicates that there were 25 students in the experimental class, and most of the students were passed the passing grades. It can be inferred that since $80 \%$ of the students were passed the passing grades, the Bits and piece game significantly affected students' achievement in writing skills of report text.

In contrast, the table revealed that only 1 student in the control class passed the passing grades. Based on Table 1, it can be inferred that the conventional teaching method did not significantly affect students' achievement in writing skills of report text.

After calculating the students' post-test scores, normality testing was conducted to figure out whether the data were normally distributed or not. Moreover, the normality testing revealed that the data were normally distributed. In the experimental class, the table told that the significance value was 0.053 at level 0.05 . It means that the value was higher than 0.05, and it can be concluded that the data in the experimental class was normally distributed. Moreover, the score of significant value in the control class was 0.060 at level 0.05. It means that the value was higher than 0.05, and it can be concluded that the data in the control class was normally distributed.

\section{The Effect Between the Use of the Bits and Pieces Game and The Conventional Teaching Method towards Students' Achievement on Writing Report Text}

\section{Table 2. The Result of Independent Sample t-test}

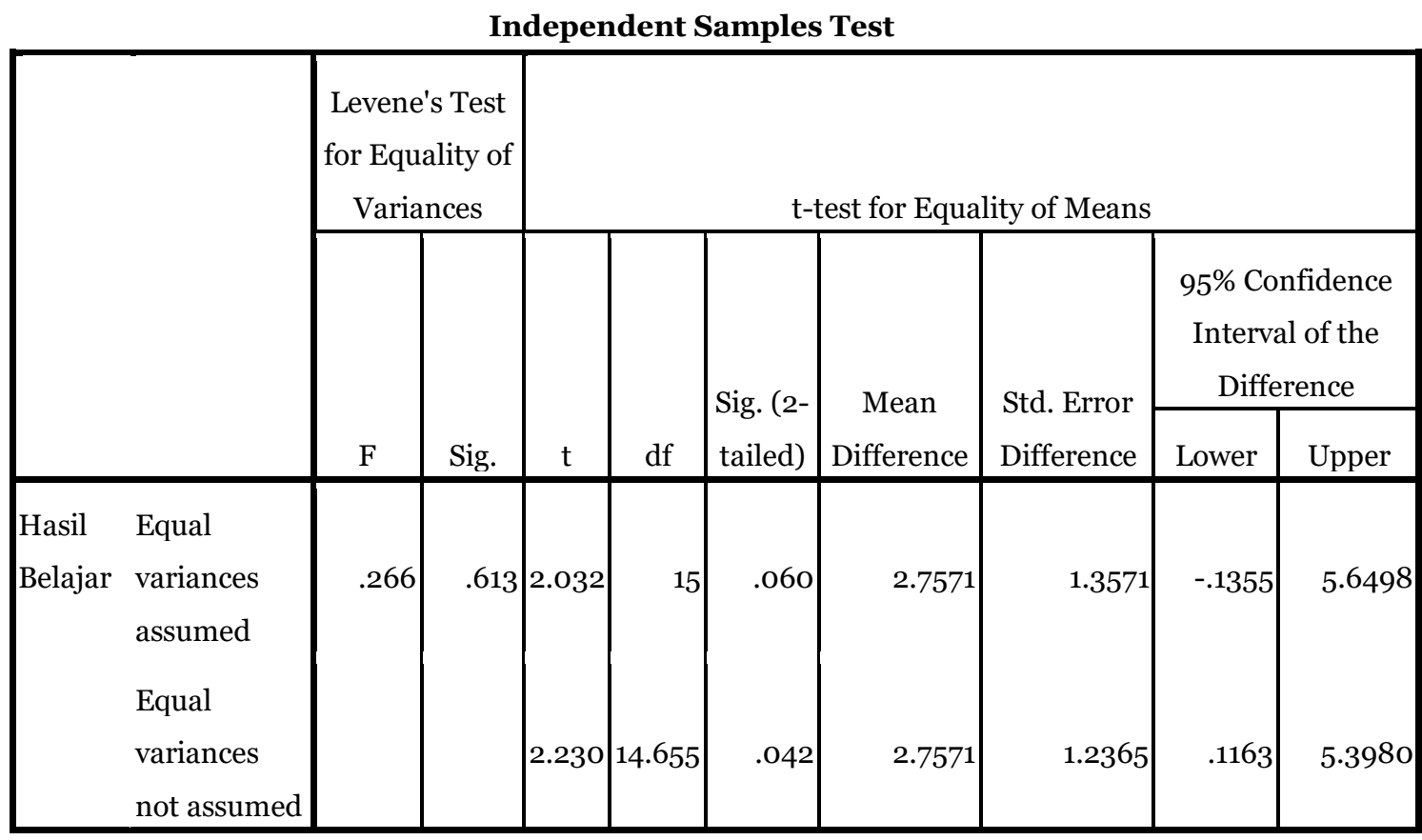

Derived from Table 5 , it can be noticed that df (degree of freedom) was 15. Moreover, the table revealed that $t_{o b s}>t_{\text {table }}$, in other words, $2.032>1.67591$ at a level significance of $5 \%$. And based on the table above, in the equal variances assumed, the score of Sig (2-tailed) was 0.060 > 0.05. It means that the null hypothesis (Ho) is rejected, and the alternative hypothesis (Ha) is accepted. So, it can be concluded that there was a significant effect of the Bits and pieces game on students' writing skills of report text.

The students showed significant effect as the result of the test. Nevertheless, from the data tabulation shown in table 1 (the post-test score of the control class), the average of the post-test score was categorized into fair. Moreover, the differences between the pre-test and post-test of the control class were not significant. It can be determined that the Conventional teaching method was not effective to be used on the writing report text. 
Initially, this research was done to see the effect between using the Bits and Pieces game and the Conventional teaching method on students' achievement on writing report text. Additionally, a quasi-experimental method was used in this research. It employed a pre-test and post-test design to extract needed data from the experimental class (EC) and control class (CC). After the pre-test was given, the researchers used the Bits and Pieces game as the treatment in the experimental class and the conventional teaching method was used in the control class.

As a result, a significant effect was found after the post-test was conducted. Moreover, this research aimed to examine the significant effect between using the Bits and Pieces game and the Conventional teaching method on students' achievement on writing report text. In analyzing the students' writing, the rubric scoring from Brown (2007) was adapted. The result also supported by Nurkhayatun (2011) and Andayani (2018). Furthermore, the Bits and pieces game has resulted from an increase in the number of words written. The participants seemed the intervention as positive provided social.

Moreover, implementing the Bits and pieces game during the learning process could encourage the students to become more interactive. The result was supported by Rojiyah (2017). She conducted research entitled "Teaching and Learning Descriptive Paragraph Writing through Bits and Pieces game at the Second Semester of the Eighth Grade of SMP Islam Nurul Iman". And she found that the use of the Bits and pieces game during the teaching-learning process resulted in improvement in the lesson plan and students' activity. Additionally, The Bits and Pieces game found out that it could be an alternative to develop students writing skills in some aspects, for instance; like content and organization. The result was supported by Andayani (2018) and Rizky (2020).

The game Bits and Pieces could accomplish the learning activity with various advantages. The advantages can be associated with the activity given to students to use the language is in a less formal situation, increases the number of conversation for individual students, is less problematic, encourages broader cooperation and negotiation skills, and promotes learners' autonomy by enabling students to engage in learning. It is a structured activity with certain characteristics, such as a specific mission or goals, a set of rules, competition between players and contact among players through spoken or written language. It also contributes to considering how the activity for active learning can be better achieved by incorporating game in the learning process.

\section{CONCLUSION}

Learning how to write through the Bits and Pieces game in the classroom can accelerate writing skills. It can stimulate extensive skills of cooperation and negotiation. The attained findings reveal that by applying the Bits and Pieces game, the students would have the more significant opportunity to learn better and expand their writing skills. The present research facilitated a new way to learn English language learning, especially in the writing report text. Consequently, future research should determine the maintenance of treatment effects whether or not in writing skills. Future research not only needs to establish if the treatment is significant for writing skills but also significant for various samples and environments. Additionally, it is expected that the teachers are highly recommended to use the Bits and Pieces game as a new strategy for learning writing skills.

\section{REFERENCES}

Andayani, M. (2018). The Effectiveness of Using Bits and Pieces Game in Students' Speaking Skill [Universitas Islam Negeri Sultan Maulana Hasanudd]. http://repository.uinbanten.ac.id/view/creators/ANDAYANI=3AMERLIN=3A=3A.html

Arikunto, S. (2013). Procedure research: A Practice Approach. PT Rineka Reserved.

Brown, H. D. (2007). Teaching by Principles: An Interactive Approach to Language Pedagogy (2nd $E d)$. Longman.

Jimmi, J. (2017). Studi Komparatif Kemampuan Menulis Bahasa Inggris Antara Strategi Belajar Induktif Dengan Strategi Belajar Deduktif. Wanastra, 9(1), 60-65.

Law, S., \& Baer, A. (2020). Using technology and structured peer reviews to enhance students' Page 305 of 306 
writing. Active Learning in Higher Education, 21(1), 23-38. https://doi.org/10.1177/1469787417740994

Lestari, L. A. (2015). The Interactional Approach To the Teaching of Writing and Its Implications for Second Language Acquisition. TEFLIN Journal - A Publication on the Teaching and Learning of English, 19(1), 42. https://doi.org/10.15639/teflinjournal.v19i1/42-56

Mukhlish, M., Hartati, U., \& Putro, D. B. W. (2021). Imperative Sentences In The Text of The Report of Observation Results in Indonesian Learning Class X. Proceedings: The International Conference on Technology, Education, and Science, 2(1).

Nafsah, S. (2016). The Effectiveness of Using Bits and Pieces Game in Teaching Writing Descriptive Text at the Seventh Grade of SMP N 40 Purworejo in the Academic year of 2015/2016. Universitas Muhammadiyah Purworejo.

Nurkhayatun, N. (2011). Using bits and pieces game to improve students' writing skill on descriptive texts (a classroom action research at the seventh grade of MTs Darul Mujahadah Prupuk-Margasari-Tegal in the academic year of 2010/2011). IAIN Walisongo.

Richards, J. C., \& Richard, W. S. (2013). Longman dictionary of language teaching and applied linguistics. Routledge.

Rizal, S. (2021). Improving Students' Speaking Skill Through Storytelling Technique. Jurnal Penelitian Tarbawi:Pendidikan Islam Dan Isu-Isu Sosial, 6(1), 45-57.

Rizky, R. (2020). "Bits and Pieces" to Improve the Students' Writing Skill: Using Educational Game as an Approach to Teach Descriptive Text. ELSYA : Journal of English Language Studies, 2(1), 20-25. https://doi.org/10.31849/elsya.v2i1.3631

Rojiyah, R. (2017). Teaching and Learning Descriptive Paragraph Writing Through Bits and Pieces Game at the Second Semester of the Eighth Grade of SMP Islam Nurul Iman Lampung Timur in the Academic Year of 2016/2017. In Thesis. State Islamic Studies University.

Sudarwati, T. M., \& Grade, E. (2007). Look Ahead: An English course for senior high school students year XI. Erlangga.

Sudjana, N. (2002). Metode Statistika. Tarsito.

Tularam, G., \& Machisella, P. (2018). Traditional vs Non-Traditional Teaching and Learning Strategies -- The Case of E-Learning!. International Journal for Mathematics Teaching and Learning, 19(1), 129-158. https://pdfs.semanticscholar.org/ea65/722ac1bb1196b2b5391c5b8fd4e4718a8d2e.pdf?_ga $=2.213544724 .1683138353 .1597811503-1985237116.1594991775$

Wang, P. L. (2015). Effects of an automated writing evaluation program: Student experiences and perceptions. Electronic Journal of Foreign Language Teaching, 12(1), 79-100. 